\title{
Comparing the Seed Cotton and Wheat Marketing Chains in Sindh
}

\author{
HaRi Ram Lohano, LaURenCE E.D. SMith, and Mike StOCKBRIDGE
}

\begin{abstract}
This paper contrasts the operation of seed cotton and wheat marketing systems in Sindh. Analysis of marketing margins indicates that the private sector cotton marketing chain appears to be working efficiently, given the many adverse aspects of its socioeconomic environment. There is evidence that higher domestic prices resulting from alignment with world markets have been transmitted through the marketing chain to producers, and that production has increased. In contrast to cotton, the government continues to be heavily involved in wheat procurement and storage, with private traders usually acting as intermediaries between the Food Department and the grower. Despite expensive involvement of the same private traders as in cotton, the wheat market is characterised by bureaucratic failure and rent-seeking behaviour, leading to stagnation of incentives and production. For cotton, the primary recommendations are to sustain liberalisation of the market and to support the developing beneficial model of private competition through improvements in communications and transport infrastructure. The practical means to improve the grading of cotton lint and seed cotton should also be developed and promoted to provide incentives for higher quality output. For wheat, the main recommendations are to liberalise farmgate prices, reduce the state's role in procurement, and privatise government godowns. Research is needed on how this might best be achieved, with attention to the conditions necessary for private financing of storage activities, and to ways of minimising price and supply fluctuations. The impact of higher flour prices on poor consumers also needs to be addressed. ${ }^{1}$
\end{abstract}

\section{INTRODUCTION}

Most growers in Sindh sell both their wheat and cotton to the same private traders (padhys). These padhys usually operate year round, buying cotton in the kharif season and wheat in the rabi season. Many also supply credit and farm inputs, usually interlocking the supply of credit with a commitment on the part of the grower to sell his output to the padhy. ${ }^{2}$

Hari Ram Lohano is Lecturer, Sindh Development Studies Centre, Sindh University. Laurence E. D. Smith is Lecturer, Wye College, University of London. Mike Stockbridge is an Independent Consultant based in the United Kingdom.

${ }^{1}$ This paper stems from research funded by the Department for International Development of the UK. However the findings, interpretations and conclusions expressed in this paper are entirely those of the authors and should not be attributed to the Department for International Development, which does not guarantee their accuracy and cannot accept any responsibility for any consequences of their use.

${ }^{2}$ More detailed analysis of these interlocked transactions through application of concepts from 'New Institutional Economics' can be found in Smith and Stockbridge (1997) and Stockbridge, Smith, and Lohano (1998). 
It is ironic that although the same padhys are the first stage in the marketing chain for both commodities, the economic performance of the two marketing systems is very different. For example, during the first half of 1997 there was a crisis in Pakistan's wheat supply system. In many towns and cities, the pre-harvest months were marked by shortages of flour. Prices rose, accusations of hoarding abounded, and in some instances there were food riots. Such events are not uncommon, and in most years are only prevented by massive wheat imports, needed to make up for the stagnation in domestic production. It is clear that Pakistan's wheat distribution system is failing to meet the needs of both consumers and producers. In contrast, the cotton marketing system has been liberalised and there is evidence that higher domestic prices resulting from the alignment with world market prices have been transmitted through the marketing chain to producers, and that production has increased.

The objectives of this paper are to compare the operation of the cotton and the wheat marketing systems in Sindh, and to identify appropriate directions for further research and reform. The main proposition investigated is that aspects of government failure and rent-seeking behaviour by public officials are the major causes of inefficiency in the wheat market.

\section{Background}

In Pakistan the private sector has always played a significant role in credit provision, input distribution, and output marketing in rural areas. Immediately after independence the private sector was dominant, but government intervention through nationalisation of commercial banks, expansion of the formal credit supply, and establishment of state-owned corporations for input supply and output procurement steadily increased through the 1960 and 1970s; ostensibly to primarily protect producers and consumers from exploitation by middlemen [Kamdar (1986)].

The exact nature of intervention, and the corresponding nature of private sector participation in service provision, has varied from service to service and crop to crop, but even where government agencies were intended to have a monopoly, their performance has tended to be so inefficient and ineffective that much activity has remained in the hands of the private sector. For example, Kamdar reports that commission agents and traders were engaged by the Sindh Seed Corporation to procure wheat seed in Sindh because the agency lacked the ability to arrange deliveries to procurement centres from widely scattered farms. Kamdar also describes government relations with the private sector that it set out to regulate as based on "compromise and barter". For example, the effectiveness of measures for licensing of traders, weights and measures, standardisation of market charges, hoarding regulations and dissemination of information were reduced by collusion between private traders and the bureaucracy. 
Liberalisation of agricultural marketing policy has, likewise, proceeded in a piecemeal fashion. For example, liberalisation of pesticide provision took place in the mid-1980s, with much claimed dramatic impacts on growth of cotton production, followed by problems caused by lack of quality control [Faruqee (1995)]. By contrast, the government still maintains a monopoly over the supply of phosphate fertiliser and competes with private companies in the supply of nitrate fertilisers. Withdrawal of the state has thus been more limited in some areas than in comparable countries that have undergone structural adjustment, yet private sector marketing services have continued to operate in parallel with the state.

Available research on agricultural marketing in Sindh is limited and tends to highlight high marketing margins, as the evidence that middlemen are exploiting farmers [Abid (1980); Memon (1978) and Siddiqui (1979)]. A contrasting contribution [Qureshi (1974)] attributes this prevailing view of trade as an exploitative and anti-social activity to the historical experience, claiming general agreement among economic historians that village markets in British India were characteristically oligoposonistic, in which farmers were offered unfavourable prices for their produce by merchant-moneylenders. After partition, market segmentation and local oligopolies of the Hindu-dominated merchant-moneylenders class were reduced by migration, and by government investment in transportation and expanded provision of formal credit. Analysing data from Sindh, Punjab, and the NWFP. Qureshi concludes that village and wholesale markets were efficient with price increases at the wholesale level passed on to farmers, and that performance of the marketing system was primarily a function of the inputs provided by other sectors, i.e., transportation, communications, and credit.

Similarly, based on favourable marketing margins ${ }^{3}$ and producers' access to the market, and in part on low intra-provincial variance in producer prices and rapid turnover of stock. Cornelisse and Naqvi (1989) conclude that private wheat traders in Pakistan "perform their limited number of functions reasonably satisfactorily and that there is no need for extending the scope of state intervention still further". (How state intervention limits the scope of private trade in wheat is described below.) Another evaluation of the wheat procurement and flour rationing systems that preceded the current situation also finds "no indication that the private sector is inefficient or uncompetitive in the transport of grain" [Alderman (1988)]. ${ }^{4}$

The availability of credit is a key issue in marketing in Sindh. The formal sector has generally failed to mobilise deposits, and has relied on inter-bank borrowing. Lending has been at non-economic rates and biased towards resourcerich farmers, wealthy traders, and other market intermediaries such as sugar mills and cotton ginneries. Loan recovery and enforcement has been poor, and approximately thirty percent of loans have ended in default. Collateral requirements are an obstacle for small farmers, particularly tenants, yet foreclosures on loans

${ }^{3} \mathrm{~A}$ price spread between consumer and producer price of 4.9 percent to 7.8 percent of the consumer price for wheat, and 16.6 percent to 27.0 percent for flour [Cornelisse and Naqvi (1989)].

${ }^{4}$ See also Alderman, Chaudhry et al. (1988). 
guaranteed by land are almost non-existent. The informal sector accounts for seventy to eighty percent of agricultural credit, but is geared to meeting demand for shortterm production and consumption loans. Commission agents and other traders are the major source of informal credit for small farmers.

Cotton and wheat are two of the most important crops in Pakistan; cotton as a cash crop and a major source of export revenue, and wheat as a staple food. Up to 1987 the cotton export trade was highly regulated; providing high levels of protection for the domestic textile industry by taxing and restricting exports of raw cotton. Tariffs on exports combined with government monopoly of the export trade to penalise cotton growers and keep the prices well below world market levels.

The first steps towards liberalising the export trade were taken in 1987 when exporting was opened to the private sector for the first time since 1973. Between 1973 and 1987 external Irade was monopolised by the Cotton Export Corporation (CEC), a government-controlled parastatal, which in addition to its role as the sole exporter was also responsible for maintaining a minimum support price for suppliers of seed cotton (growers) and suppliers of cotton lint (ginners). However, the CEC never played a significant part in the procurement of seed cotton as the support price tended to lie beneath the market price. Private traders (padhys) have always dominated this part of the marketing chain, acting as the main link between growers and the ginning factories. By 1993-94 the CEC was in serious financial difficulty, and it has not purchased cotton since then. Since 1994 all exports have been in the hands of the private sector, and in February 1995 the government removed all remaining duties and restrictions on the export of cotton. Of particular interest is whether the higher domestic prices resulting from alignment with world market prices (Figure 1) have been transmitted through the marketing chain to producers.

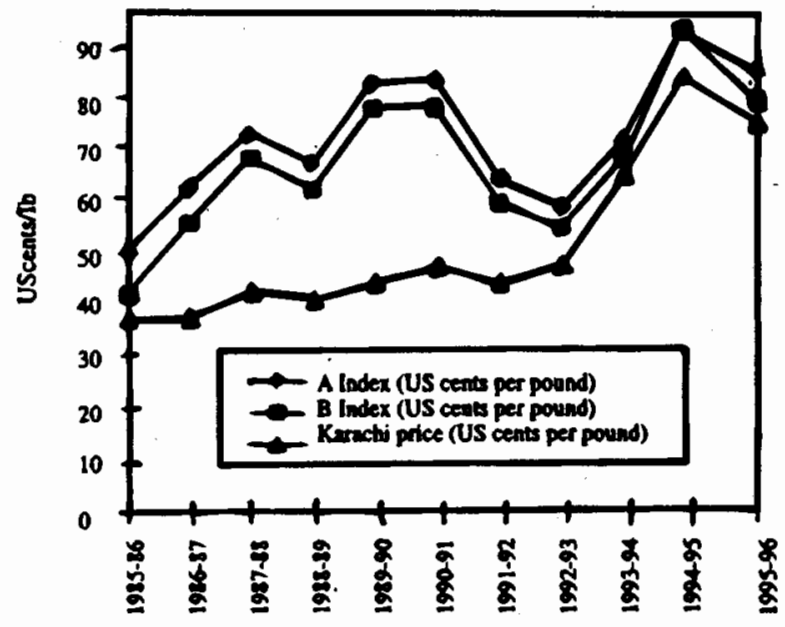

Fig. 1. North Europe CIF Price, A\&B Index Compared to Karachi Wholesale Price of Cotton Lint. 
In contrast to cotton, the government has been, and continues to be, heavily involved in wheat procurement and storage, with private sector traders usually acting as intermediaries between the Food Department and the grower. Between 1980 and 1990, approximately twenty-eight percent of the annual wheat harvest was procured by the government. More recent estimates suggest that this has fallen to about twenty-four percent [Khan (1994)], but this remains high given that less than a third of the annual crop is actually marketed. ${ }^{5}$ Producer prices for wheat are largely determined by the pan-territorial, government minimum support price at which the Food Department purchases wheat. This price is considered, by growers and economists alike, to be uneconomically low, although in remoter regions it may be higher than would be the case under free-market conditions due to the government subsidy on transport. Pakistan is normally a net importer of wheat, although it does have the potential to be an exporter [John Mellor Associates, Inc. (1993)]. The government monopolises the import of wheat, which it distributes to flour mills at subsidised prices, putting further downward pressure on farmgate prices. In addition to the penalties it imposes on growers, the government's wheat policy is a major drain on public sector resources. This policy has been largely unchanged since 1987, when a partially targeted but inefficient subsidy on flour available through ration shops was removed and the general subsidy on wheat instituted [Alderman (1988)].

\section{Methodology}

Field investigations were carried out between October 1996 and January 1997, and were concentrated in Sanghar district of Sindh. An exploratory survey based on informal interviews with growers, padhys, and cotton ginners in the districts of Sanghar, Mirpurkhas, and Nawabshah concluded that marketing conditions in this district were sufficiently representative of cotton-wheat zone in Sindh to justify this focus. Data collection involved semi-formal interviews conducted with an extensive checklist of questions, combined with more open-ended discussion with key informants. ${ }^{6}$ Interviews were conducted with: 20 padhys (11 from Sanghar town, the district capital, and a further 9 from surrounding towns and villages); 6 input dealerships; 70 growers (60 landowners and 10 sharecroppers); 4 cotton ginners; 3 flour milers; and 2 transport agencies. Some of these respondents developed into "key informants" and were met on several occasions. They became an important source of information on more detailed and sensitive issues. Officials from the Food Department, the Pakistan Central Cotton Committee, the Pakistan Cotton Standard Institute, the Karachi Cotton Association, the Department of Agricultural Extension and other institutions also furnished important information.

${ }^{5}$ Cornelisse and Naqvi (1989) cite the figure of 25 percent of the harvest procured, equivalent to 60 percent of the marketable surplus, given that only 40 percent of the harvest is sold.

${ }^{6}$ The primary focus of the investigation was to gain an understanding of interlocked transactions in the credit, input, and output markets as reported elsewhere [Smith and Stockbridge (1997); Stockbridge, Smith, and Lohano (1998)]. Hence collection of quantitative data that could be used to test the efficiency of the marketing systems was limited. 
Sampling of respondents was informal and the sample small, because of the need to establish the trust and co-operation required for the detailed and probing interviews. To ensure the sample was as representative as possible, the selection was purposively stratified. For example, padhys varying in their scale of trading were interviewed from both Sanghar town and surrounding villages, including more isolated parts of the district. Growers interviewed also included a range of respondents in terms of location, land tenure, and socio-economic status. ${ }^{7}$ The exception was the relative neglect of sharecroppers (hairs) because of their limited interaction with the marketing system. ${ }^{8}$

\section{THE COTTON MARKETING SYSTEM}

There are three principal actors in the marketing chain for seed cotton in Sindh: landowning farmers (zamindars), padhys, and cotton ginners (Figure 2). The majority of seed cotton is sold by zamindars to padhys who then sell it to cotton ginners. A smaller percentage is sold by zamindars, usually those with larger farms, direct to the factories [Khushk et al. (1988) ]. The kanthy, who assembles small quantities of cotton and sells either direct to factories or to padhys, is a less significant actor in terms of volume of trade.

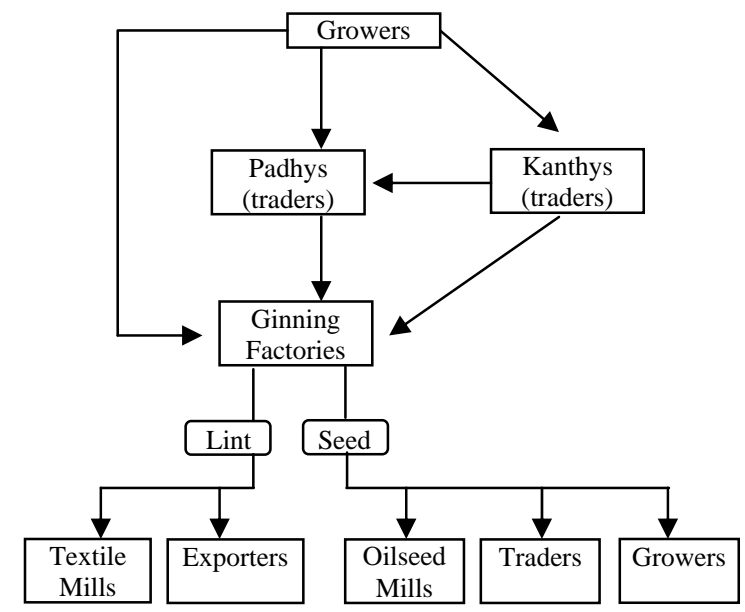

Fig. 2. The Cotton Marketing Chain in Sindh.

${ }^{7}$ Of the 60 growers interviewed: 55 percent owned less than 25 acres, 20 percent 25 to 50 acres, 8 percent 50 to 100 acres, and 17 percent over 100 acres; approximately reflecting population characteristics identified by secondary sources [SDSC (1991)].

${ }^{8}$ Crop marketing is usually conducted by the landlord (zamindar) or his overseer. Since their share of the wheat crop is received in kind, wheat is sometimes sold by sharecroppers, but this generally only applies to any residual surplus (after home consumption and retained seed) or to distress sales. Cotton is almost always marketed by the zamindar. 
Cotton ginning factories, located throughout the main production areas, process seed cotton into cotton lint and cotton seed. The lint is sold via brokers, either to spinners located in large urban centres such as Hyderabad and Karachi, or to exporters. The seed is sold, again via brokers, to oilseed factories that produce cotton seed oil and seed cake. A small percentage of seed is sometimes supplied to padhys and large zamindars for planting.

Padhy is a Sindhi word that traditionally refers to the shop where seeds and farm produce are traded. The padhy wallah is the person who owns and runs the "shop". In most of the literature on agricultural marketing in Pakistan, padhy wallahs are referred to as commission agents or, in Urdu, beoparis or arthis. These terms are often treated as synonymous, although in Sindh the activities of the padhy generally extend for beyond what is implied by the English term "commission agent". Padhys dealing in cotton stress that they take full ownership of the commodity traded, and are subject to all of the risks and responsibilities associated with ownership. The same applies to padhys able to purchase and distribute wheat in private markets. In the government wheat procurement system, however, the activities of padhys are more akin to those of a commission agent, arranging transport from farm to procurement centre or godown in return for a modest commission or margin (see further details in Section 3 below).

The main function of padhys in cotton marketing is to link growers and ginners, and to arrange for the physical transportation of cotton from farm to factory. The latter is usually accomplished by contracting with local transport companies. Village padhys also serve as important assembly points for cotton. Growers usually approach padhys when they want to sell their crop rather than the other way round.

Kanthy wallahs are small-scale padhys who, unlike padhys, are not normally involved in supplying inputs or credit. They assemble small amounts of cotton, which they sell either to padhys or, more commonly, direct to cotton factories. During the rabi season some kanthy wallahs also buy wheat and trade in other commodities, such as rice, chillies, and peanuts, their name derives from the Urdu word kanta, which means a weighing machine or balance. Some locate themselves temporarily at strategic road junctions in the rural areas, often close to a tea-shop. Others own or rent more permanent premises in towns and villages.

Because of the small quantities involved, kanthys generally buy from zamindars who have cultivated only small amounts of cotton; from hired labourers who, at the end of the harvest season, are sometimes paid in kind for cotton picking; and from poor people, especially children, who have managed to scavenge small quantities from the roadside or elsewhere. Thus they often accept lower quality cotton than padhys are prepared to. Kanthys do not themselves arrange for transport from the farmgate- this is done by their suppliers. They do, however, arrange for transport from their site to the factory. Investment needs are minimal and the activity is therefore open to those with very limited capital. 
In 1996 there were thirty-six cotton ginning factories operating in Sanghar district, and approximately a further one-hundred-and-thirty throughout the remainder of the province. They typically operate for about six months of the year. Before being ginned the seed cotton is spread out to dry in the factory's large open compound where poorer quality seed cotton is usually separated from the better quality product. The output from cotton ginning consists of weight of about two parts cotton seed and one part cotton lint. About one kg. out of every one-hundred-andtwenty kg. is waste material; the dried out bowls of the cotton seed plus dirt and dust.

The main function of the ginners is processing, but they also provide credit services to padhys and zamindars. This is usually on an interest-free basis. The main purpose of lending, from the ginners' point of view, is to have the means of securing supplies. Loans are provided under what is called the cabaro contract. This is a formal document in which the conditions of the agreement are clearly laid out. The borrower is required to supply a quantity of seed cotton to the factory; usually an amount equivalent to one maund of seed cotton for every 50-100 rupees borrowed. Repayment of the loan is deducted from the amount paid to the borrower for the seed cotton supplied. The price paid for the delivery is the prevailing market price at the time of supply, unless supplier and ginner have entered into other arrangements for storage and delay of price determination as described below. The penalty for failing to meet the obligation to supply seed cotton is a five percent per month interest charge on the outstanding loan. Factories also store cotton, either as un-processed seed cotton or as lint.

Transport agencies provide their services, either as part of a seasonal contract with padhys, or on ad hoc basis. Seasonal contracts are usually informal agreements to provide transport for the duration of the picking season. The transport company usually agrees in advance to provide a specified number of trucks per day. Agreements of this sort also specify prices for particular routes at the start of the harvesting season. The rates are typically lower than the spot market rates prevailing once harvesting is well under way. Under these seasonal contracts the padhys usually pay a deposit at the beginning of the season equal to the value of five to ten trips. Payments for transport services are usually made in arrears, although the time for settlement of accounts is very flexible, ranging from days to months. Trucking services provided on ad hoc basis are normally paid for within a few days of delivery, whereas in seasonal contracts a significant proportion of invoices may not be settled until the end of the season.

Transport services are charged on a mileage basis, with an additional charge being levied for labour engaged by the trucking company for loading and unloading. There is a certain amount of flexibility in pricing, with valued regular customers often receiving better rates than others. There does not appear to be any price collusion between agencies, and there is no formal association to facilitate this. Most padhys report that the transport agencies provide them with a competitive service. 
The number of agencies has reportedly increased in recent years in line with the increasing production of cotton in the area. The transporter is responsible for any cotton that is stolen during transit, but if the cotton is damaged or destroyed by accident, for example by fire, the padhy bears the cost.

Transactions in the seed cotton marketing system primarily occur: (a) between the padhy and the zamindar; (b) between the padhy and the factory; and (c) between the zamindar and the factory. Transactions between zamindars and padhys can be disaggregated into transactions in the output market, those in input markets, and those in the credit market. Some zamindars only deal with padhys in the output market. However, for many zamindars transactions in these three markets are combined into a single contract, although the precise terms of the contract are not settled until harvest time.

A typical transaction in the output market begins when a zamindar arrives at the padhy's shop to negotiate the sale of harvested cotton. It is at this point that a price is agreed between the two parties. Although there is no written contract, the zamindar and the padhy are nevertheless morally bound to adhere to the agreed price. The price is determined on a per maund (40 kgs.) basis, by an approximate deduction of the padhy's expenses and profit margin from the day's factory price (see Table 1). The exact break-down of the marketing margin is not usually made explicit in the price negotiation. All padhys in the town have a telephone and are in daily contact with factories from which they obtain price quotations. Most zamindars get price quotations from other padhys before they agree on a sale price. They also get information on prices received, from other zamindars. Through informal information networks some zamindars are also aware of the prevailing factory prices. All respondents, including those that had taken loans from padhys, stressed that the price received for cotton is based on the prevailing market price. It is never agreed in advance of harvest time and sale.

The figures in Table 1 are an approximation only. Unit transport charges vary

Table 1

Marketing Margin—From Farmgate to Gate of Cotton Ginning Factory, Sindh, November 1996

\begin{tabular}{lcc}
\hline & Rs Per 40 kgs. & $\begin{array}{c}\text { Percentage of Total } \\
\text { Margin }\end{array}$ \\
\hline Factory Gate Price (in November) & 850 & 12 \\
Weighing & 3 & 24 \\
Transport & 6 & 12 \\
Loading and Unloading & 3 & 20 \\
Factory Charges (Including Local Taxes) & 5 & 32 \\
Padhy's Margin (Including Overheads and Profit) & 8 & 100 \\
Total Margin & 25 & \\
Farmgate Price & 825 & \\
\hline
\end{tabular}


with distance. The padhy's profit margin is also subject to some variation. Some padhys reported charging commission worth ten or eleven rupees per maund. Others claimed to only charge five or six rupees per maund. Variations in the actual profit margin obtained are sometimes greater still. This is because prices offered by factories vary daily, occasionally by as much as plus or minus fifty rupees. As padhys often agree on the farmgate price a few days prior to agreeing a price on delivery with the factory, their profits can vary greatly from one transaction to another. Padhys compete on price, as do factories, and zamindars with large quantities to supply are sometimes offered above-average prices. This is particularly the case if a padhy anticipates being able to sell a large volume to a factory offering a premium over and above what is currently being offered by other factories, or if they expect prices to rise in the near future.

The cotton price agreement between the padhy and the factory either takes place over the phone, especially in the case of more distant factories, or is made at the factory itself. The agreement is normally made within a few days of purchasing agreements between the padhy and the zamindar. It states the volume of seed cotton to be delivered and the price per maund. The agreement is an informal one, but, once agreed, it is morally binding. Neither party is expected to seek a re-negotiation of the price. The price is established on the basis of a standard formula (Box 1) that converts the market price for lint and cotton seed into a price for unprocessed seed.

\section{Box 1: Seed Cotton at Factory Gate: Formula for Price Determination}

Example based upon November 1996 price:

Price of $37.32 \mathrm{kgs}$. of cotton lint

Price of 37.32 kgs. of cotton seed

$\mathrm{x} 2$

Value of ( $3 \times 37.32) \mathrm{kgs}$. seed cotton

Subtract factory margin:

(Rs 250 reported on average)

Rs 2,631 - Rs 250

Value of 37.32 kgs. seed cotton

Factory price of one maund (40 kgs.)

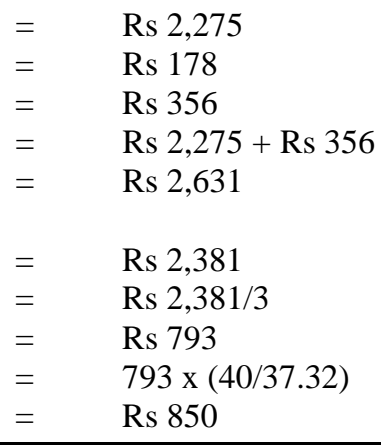

A committee of six buyers (textile mills and exporters), six sellers (ginners and growers), and one government official meets each day at the Karachi Cotton Exchange under the guidance of the Karachi Cotton Association. They agree upon the average price at which the lint transactions have been taking place. This becomes the official "upcountry" spot price of lint that is quoted daily by the Karachi Cotton Association and published, after the addition of sales tax and the cost of transport to Karachi, in the national newspapers. Ginners obtain daily price quotations from 
brokers at the KCE. They also get price quotations from brokers dealing in cotton seed, or direct from oilseed factories. Seed brokers and oilseed factories are located in various urban centres. Prices are quoted on the basis of the old maund, which is equivalent to $37.32 \mathrm{kgs}$. The output of cotton ginning results in two parts cotton seed, one part cotton lint, and a small, negligible amount of waste. Although the weight of seed is twice that of lint, the unit value of lint is more than ten times that of seed. Hence, it is primarily the lint price that determines the price of seed cotton. To establish the ex-factory value of $111.96 \mathrm{kgs}$. ( 3 x $37.32 \mathrm{kgs}$.) of processed seed cotton, the seed price is multiplied by two and added to the lint price. The factory ginning margin, which includes profit, is deducted from the resulting figure to give the factory gate price for three "old" maunds of seed cotton. This is then converted to a price for a $40 \mathrm{kgs}$. maund, which then forms the basis for farm gate prices offered by padhys to zamindars. All padhys interviewed were familiar with this formula.

The factory's margin is sometimes open to negotiation, especially for large suppliers. It also varies slightly during the ginning season according to supply and demand. Hence, when the supply of seed cotton is low at the beginning of the picking season, the margin tends to be lower as factories compete for scarce supplies by offering high prices. At peak harvesting time, between September and October, when factories are operating at full capacity, the prices offered fall and the factory margin may increase. The cotton harvest in Punjab, the largest cotton producing province, starts about a month or so later than in Sindh and has a major impact on prices, both nationally and in Sindh. Prices in Sindh tend to be high until the Punjab cotton becomes available.

In addition to price variation resulting from seasonal changes in the volume of cotton being harvested, there are also significant daily price fluctuations. These stem from uncertainty regarding the final size of the annual cotton harvest and from speculation concerning the effects of pest and disease in different parts of the country. Because of the daily fluctuation in factory prices some padhys prefer to negotiate a price with the factory on the same day, or even the same hour, as they negotiate the farmgate price. In this way, they avoid potential losses from downward price movements. Others prefer a more risky strategy, opting instead to speculate on price rises. Following the delivery of cotton to the factory, padhys are permitted to "store" the cotton for up to two or three months before finally agreeing on a price. This storage service is interlocked with an obligation to sell to the factory after a specified time. Factories pay sellers approximately two-thirds of the estimated price on delivery. The balance is paid at a later date and is based upon the prevailing market price at that point in time. This practice allows padhys to speculate on price over a period longer than the few days that pass between agreement on price with the zamindar and delivery to the factory. For the factory, it helps to ease cash flow constraints during the peak harvesting period, and helps to guarantee a constant throughput from a well-stocked yard.

Occasionally padhys pass on this "storage service" to zamindars. Under this arrangement, the price agreement between the padhy and the zamindar is deferred for the duration of "storage", typically one to two months following delivery to the 
factory. The zamindar receives part-payment in advance, as does the padhy, and collects the balance when the price is agreed. This practice is not common amongst zamindars with small and medium sized farms, primarily because they can neither afford the risk, nor the delay in payment.

Grading by ginners is not very sophisticated. It is based primarily upon visual and manual inspection, although a measuring device is sometimes used for estimating moisture content. Cotton is usually divided into A and B, and sometimes $\mathrm{C}$ grade quality. The grade depends in part on the ratio of cotton lint to the whole. The higher the ratio, the more likely it is that cotton will fall into the A category. This is because the lint is the most valuable part of the product. The more impurities there are, such as moisture, dirt, and twigs, the more likely it is for the cotton to be classified as B or C grade. For poor quality cotton, deductions are made from the measured weight of the cotton before payment is made. At factories without modern weighbridge facilities, delays in weighing can result in moisture loss and dissatisfaction for the supplying padhy or zamindar.

The best quality cotton usually arrives during the early part of the harvesting period. Many ginners store high quality cotton from this time, for sale as lint later in the season - when the quality from standing crops has diminished, high quality is in short supply, and the quality premium is high. Because there is no standard grading system at cotton factories, it is debatable whether padhys who have postponed fixing the price of delivered cotton for speculative purposes will benefit fully from the seasonal appreciation in this quality premium. Once delivered to the factory, a padhy's cotton is not stored and sold separately from other deliveries. Seed cotton varies in terms of fibre/staple quality but none of the ginners visited grade their cotton purchases according to variety, although the Karachi Cotton Association does provide daily lint price quotations for different varieties.

Transactions between ginners and zamindars are similar to those between ginners and padhys, except that factories may arrange the transport of cotton to the factory for zamindars. Ginners interviewed expressed a preference for dealing with padhys rather than zamindars. This preference was reflected by the relatively small proportion of seed cotton (around thirty percent) supplied to them by zamindars. Reasons given included problems associated with the enforcement of contracts. Zamindars with larger holdings-generally the only growers who sell direct to factories-are more likely to renege on agreements, both with respect to pre-agreed prices and supply commitments. Enforcing loan repayments and penalties for breach of a cabaro contract is also considered to be potentially problematic when dealing with influential zamindars.

Table 2 shows estimates of marketing margins at various stages of the cotton marketing chain, starting with seed cotton at the farmgate and ending with cotton lint and cotton seed in the Karachi wholesale market. The total marketing margin, including ginning, is about twenty percent of the Karachi wholesale value of the lint and seed produced by $40 \mathrm{kgs}$. of seed cotton, with about eighty percent going to the 
grower. The largest component of the total margin is the ginning margin, followed by the sales tax on cotton lint. The margin between the farmgate and the ginning factory is much smaller than either of these, and about a third of it accrues to the padhy as a margin covering overheads and profit. This is equivalent to a little under one percent of the Karachi value of processed and marketed seed cotton. The ginner's margin is more than double that of the padhy, which is partly to be expected given the high investment costs of ginning. Although it is difficult to evaluate the efficiency or performance of a marketing system by margin analysis alone, especially since it does not account for quality issues, the evidence presented in Table 2 suggests that the cotton marketing system in Sindh is operating with a reasonable degree of efficiency. Indeed, were it not for the government sales tax that accounts for over a third of the total margin, the marketing margin would be even narrower.

Figure 3 compares estimated farmgate prices for seed cotton between the beginning of August 1996 and the end of January 1997 with those reported by respondents in the survey. The estimated prices are based on daily spot prices for lint and seed in Karachi and the estimates of marketing and processing costs are given in Table 2. The comparison shows that the prices reported fall within the expected range, confirming the validity of the marketing margin analysis in Table 2.

Table 2

Marketing Margins for Seed Cotton, Sindh, 1996-97

\begin{tabular}{lcccc}
\hline & $\begin{array}{r}\text { Rs/40 kgs. Seed } \\
\text { Cotton Equivalent }\end{array}$ & $\begin{array}{c}\text { Margin as a Percentage } \\
\text { of Karachi Wholesale }\end{array}$ \\
Margins & 835 & & 79.6 & \\
\hline Average Farmgate Price & 25 & 3 & 2.4 & 0.3 \\
1. Farmgate to Factory-gate: & & 6 & & 0.6 \\
$\quad$ Weighing & & 3 & & 0.3 \\
$\quad$ Transport & & 5 & & 0.5 \\
Handling & & 8 & & 0.8 \\
$\quad$ Factory Charges Incl. Local Taxes & & & 8.5 & \\
$\quad$ Padhy's Margin & & 71 & & 6.8 \\
2. Ginning: & & 18 & & 1.7 \\
$\quad$ Ginning Costs & 79 & & 7.5 & \\
$\quad$ Ginner's Margin & 21 & & 2 & \\
3. Sales Tax & 214 & & 20.4 & \\
4. Ginnery to Karachi Expenses & 1049 & & 100 & \\
TOTAL MARGIN & &
\end{tabular}

Source: Survey 1996. 
Farmgate Price Based on Karachi Spot Market Prices Adjusted for Marketing and Processing

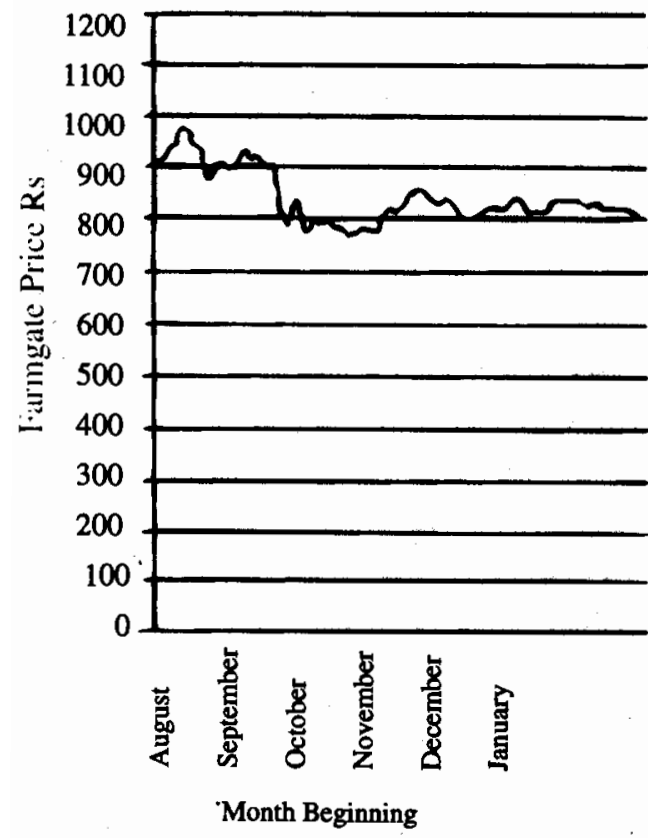

Farmgate Prices Reported by Survey Respondents

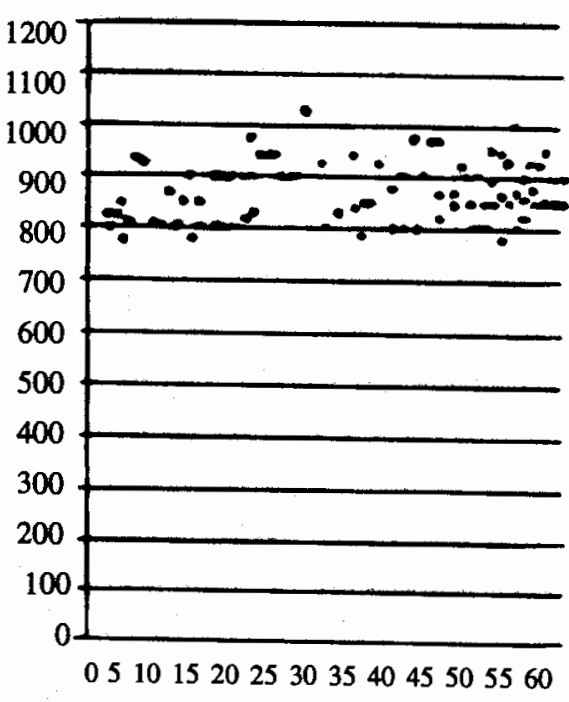

Grower Respondent Number

Fig. 3. Farmgate Prices-survey Prices Compared to Prices Bases on Estimated Margins.

\section{THE WHEAT MARKETING SYSTEM}

Unlike the cotton marketing system, wheat marketing in Pakistan is still characterised by considerable government intervention (Figure 4). Wheat prices at harvest time are determined by the government support prices at which the Food Department purchases wheat. Wheat purchased by the Food Department is stored in government godowns, which are located throughout the country. The distribution of these wheat stocks is regulated by the government. Wheat from the godowns is used to supply other godowns in deficit areas or sold directly to the local privately-owned flour mills. Flour mills throughout the country are allocated quotas by the Food Department to purchase government wheat stocks. To fulfil these quotas, the government also imports substantial volumes of wheat. 


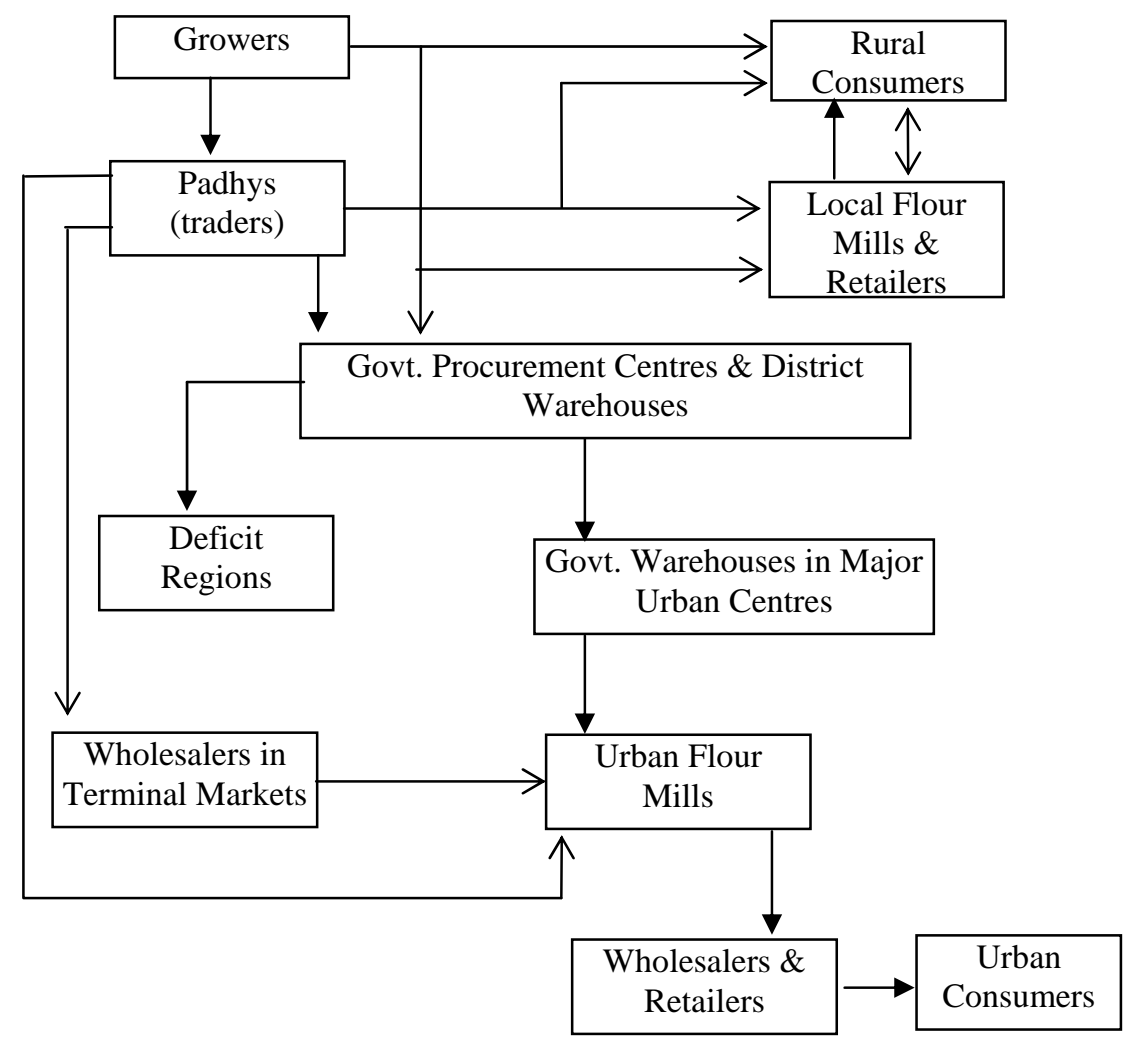

Fig. 4. The Wheat Marketing Chain in Sindh.

Private sector marketing operates in parallel with the government distribution system. In the private system, wheat channelled from producers to flour mills bypasses the government procurement process. However, at the beginning of the harvest season, district authorities often impose a ban on the movement of wheat outside the district. This is kept in force until the Food Department has met its procurement obligations and local godowns have been filled. How rigorously the bans are enforced is unclear, though this clearly provides opportunities for rentseeking. Some padhys are provided with special permits to sell wheat outside the district during the ban, when prices in the main urban centres are still high. Padhys play a crucial role in both private and government distribution systems. In the private system, they assemble wheat from farms and sell it direct to flour mills, either small 
local ones or, when possible, to the larger ones located in urban centres. In the public procurement system, padhys act as intermediaries between the Food Department and the grower, providing the latter with bags and payment from the former. Padhys carry out some storage activities but this is limited, as there are restrictions on the volume of wheat that padhys are permitted to store. Flour mills also purchase wheat direct from some of the larger zamindars.

Flour mills can be divided into two categories. There are small, low-capacity enterprises such as those located in Sanghar town and many of the villages in the district, and the much larger mills located in major urban centres such as Hyderabad and Karachi. Wheat milled by the small flour mills in a town such as Sanghar is either retailed as flour or returned to private households which pay for custom milling services. Some storage is carried out by small flour mills, but this does not appear to be on a large scale, and most wheat is milled fairly soon after purchase.

During the first six months after the beginning of the wheat harvest, small flour mills in Sanghar reported receiving most of their wheat supplies direct from padhys and zamindars. However, from September through to March, local mills purchase most of their wheat from the Food Department according to quotas. The quotas are determined by the Food Department and are based on the mills' milling capacity. For all mills, records of electricity usage are the main indicator of the milling capacity used. The Food Department releases its stocks onto the local market when shortages begin to drive up market prices. The prices at which these buffer stocks are released are determined by the government. The local administration publishes guideline prices for flour sales but there is little enforcement of these and they are sometimes exceeded.

During times of shortage, there are considerable opportunities for arbitrage between the price at which the government is releasing its stocks and the price that large mills in urban centres are prepared to pay in order to supplement the quotas allocated by the Food Department. Only fifty to sixty percent of wheat milled in Karachi is supplied by government quotas, the remainder being purchased on the open market. In the first half of 1996 the government supplied wheat to flour mills for Rs 486 per 100 kgs. (Rs 194 per maund), and during the wheat harvest (MarchJuly), the open market price was higher by Rs 35-40. This price premium increased to Rs $40-80$ per $100 \mathrm{kgs}$. in the following months. By November 1996, the government issue price had risen to Rs 515 per 100 kgs., whilst the open market premium exceeded Rs 100, as market prices ranged from Rs 610-630.

In Sanghar, as in other parts of the province, this resulted in the "leakage" of government stocks into the private sector marketing system. This is reportedly facilitated by abuses of the quota system. The authorities at the government godowns keep lists of local flour mills. Allegedly, the lists include many mills that exist in name only: some existed in the past but have since closed down; others exist but are not operating. It was estimated by a high level official in the provincial Food 
Department that seventy percent of the officially listed mills in Sanghar district were not operating. Of these forty percent do not even exist. Yet all the flour mills listed may be allocated a quota.

A key informant reported how some padhys are able to purchase wheat from the government godown at a premium over the official government sale price, a premium which can only accrue as a rent to officials at the Food Department. The padhys sell the wheat thus acquired to large mills in the main urban centres. Many mills are allocated quotas far in excess of their actual milling capacity if their owners have sufficient power and influence. There is clearly an incentive for any mill, large or small, that is operating inefficiently, suffering from mechanical breakdowns or able to gain supply above its quota, to sell on the open market. Thus there are many opportunities for subsidised quotas to be diverted into the private sector marketing system, with powerful and influential actors benefiting most from the large rents that accrue from the difference between subsidised wheat prices and market prices. In 1997 there were also frequent reports of wheat being smuggled across the border into India, Afghanistan, and the Central Asian Republics, where wheat fetched a higher price than on the domestic market. At the same time the government continued to import wheat at great cost.

In the government procurement system wheat is sold by padhys and zamindars to a government wheat inspector from the Food Department, who "officially" sits at strategically located procurement centres scattered throughout the rural areas. Under the official system, licensed government wheat contractors are then supposed to make arrangements for transporting wheat to a government godown, usually located in or near the closest sizeable town. In practice, in Sanghar district, a significant proportion (15-20 percent) of the procurement centres exist only on paper-the wheat inspector is to be found instead at the government godown.

Nearly all the zamindars with small- and medium-sized holdings who were interviewed sold their wheat surplus to padhys. Usually, as with cotton marketing, they sold to the padhy from whom they had borrowed. The padhys sold the wheat to the inspector at the government godown or, where operating, at a designated procurement centre. Sales to the government inspector at the godown are logged as having taken place at an official procurement centre, even if the wheat never actually went anywhere near one. Payment is made to the padhy at the official government procurement price in the form of a banker's draft or cash. Zamindars are usually paid by padhys in cash. The price they receive is typically about two rupees per maund less than the official procurement price, this amount going to the padhy as "commission". 9

${ }^{9}$ This indicates the low marketing margin of padhys, confirming, as noted by earlier studies, that they perform their limited functions in the wheat market cost-effectively and probably efficiently. 
In most cases, the padhy will arranged and pay for transportation of the wheat from the farm or padhy shop to the godown. The government will bear the cost of transporting wheat from the procurement centres to the godown, but reimbursement for this can only be made to official contractors. Padhys and contractors often enter into an agreement to overcome this bureaucratic problem. Under this agreement, which is unofficially sanctioned by the government inspector, wheat deliveries made to the godown by a padhy are registered as having been made by a contractor and the contractor reimburses the padhy. The contractor is later able to recover this amount from the Food Department by invoicing for the cost of transport between a specified procurement centre and the godown. In other cases, the padhy acts as a sort of commission agent between the zamindar and the contractor, securing supplies for the contractor to transport, whilst receiving payment for the wheat itself from the food inspector.

It is not clear how the amounts for reimbursement to contractors for transport are established, and there is considerable opportunity for rent-seeking on the part of both government officials and contractors. It is reported, for example, that wheat only transported a short distance is logged as having come from more distant "procurement centres".

In 1996 there were only fifteen to twenty wheat contractors in the district of Sanghar. The numbers have fallen considerably in recent years; respondents estimated that there were about two hundred active contractors in the past. Anyone may apply to become a contractor, but it is clear that the most lucrative contracts are allocated to powerful and influential people. Contractors, or members of their family, are also often padhys. Licences have to be reapplied for in January of each year. There are three grades of contractor: A, B, and C. C-grade contractors are only licensed to transport wheat from procurement centres to the local godown; B-grade contractors are additionally licensed to transport wheat between major towns of the district; A-grade contractors are licensed for long-distance transport to the major cities in the province such as Karachi and Hyderabad.

Contracts for transport between godowns and major urban centres are officially allocated through competitive tendering by contractors, but in practice there seems to be little competition. Contractors reportedly meet together and divide the major haulage routes and procurement centres between them prior to the tendering process. They agree not to compete against each other for contracts on these routes. Tenders for transport contracts are submitted to the Food Department on a cost per $100 \mathrm{~kg}$. bag basis. It is alleged that tenders commonly include an inducement for officials from the Food Department.

It is unclear what the relationship is between the value of the government reimbursement and the real cost of the transport activities that are carried out by contractors and, in the case of farm to godown haulage, by padhys. The magnitude of rent-seeking is therefore difficult to ascertain. Nor is it clear how the rents are 
distributed between contractor, government inspector, and padhy. Key informants suggest that the price paid by the Food Department for transporting a truck of wheat is significantly higher than the actual costs. An example was given of reimbursements of Rs 60 per 100 kgs., for haulage that actually cost Rs 30, with the remaining Rs 30 being divided between the Food Department officials and the contractor.

Contractors are usually paid in arears for their services, be they local or longdistance haulage contracts. A contractor interviewed complained that payments were often delayed for many weeks or even months, and in January 1997 he was still owed over one million rupees by the Food Department. The padhys who arrange transport to the local godowns on behalf of contractors generally get paid more promptly by the contractors, as do the transport agents who actually carry out the transportation. The contractor suggested that payment delays and "the Inspector's cut" were the justifications for the high transport costs that contractors sometimes claim. The payment delays were also causing the same contractor to reconsider whether or not to reapply for a wheat contractor's licence next year. ${ }^{10}$

Contractors vary considerably in the size of their contracts and perhaps also in their ability to get paid promptly. However, if there were many more contractors in the past than there are now, as seems to be the case, it is possible that payment delays to all but the most powerful have served to squeeze out competition and consolidate the position and number of contracts held by the largest contractors. The economic rents for these are undoubtedly enormous. An informant gave an example of the contract to transport government-imported wheat from Karachi to various parts of the country, including the far north. It is claimed that after leaving the port, much of this wheat goes no further than the Karachi Market, where it is sold at the open market price. Official records, however, will show the wheat recorded as having arrived at various godowns throughout the country, as having been sold at the government-subsidised price to local flour mills under the quota system, and as having been milled and retailed. It is very difficult to substantiate or quantify the level of corruption in the wheat distribution system, for the obvious reason that the individuals who are best informed about what is really going on are very reluctant to speak openly about it.

\section{CONCLUSIONS}

Although formal analytical methods have not been applied, the cotton marketing system in Sindh appears to be relatively competitive and efficient. Recent liberalisation has increased the incentives to produce cotton and the benefits of higher prices have on the whole been transmitted to zamindars. There is considerable

${ }^{10} \mathrm{An}$ interesting contrast to the observation by Cornelisse and Naqvi (1989) that "traders like to sell to procurement depots which have a reputation for paying promptly"; and a change perhaps indicative of deterioration in public finances and management. 
competition in the marketing system in Sindh, with a large number of padhys and factories in the area, the numbers of which have increased in recent years. The majority of zamindars reported having a greater choice of padhys to sell their cotton to than was the case in the past. In Sindh, over the last few years favourable prices, good weather, and improved levels of cotton production have encouraged new entrants, both as traders and processors. Relatively good communications, particularly by phone, have also improved the availability of price information to producers and enhanced the competition between padhys and ginners.

Competition reduces marketing costs and raises the prices received by growers, but it also increases the incentive for producers to default on loans, posing a potential threat to sustained lending by traders. Given the failures of the formal credit system, ginners and padhys are playing the vital role of providing most of the seasonal working capital required by zamindars to cultivate the cotton crop. This lending only takes place if loan repayments can be enforced, and this is achieved by interlocking borrowing with the obligation to supply seed cotton to the lender. This is backed up by the threat of being labelled non-credit-worthy and of being excluded from access to informal credit. This mechanism depends on the existence of informal information networks within the trading community, local village communities, and the wider community. Information-sharing between padhys reduces the incidence of loan default, allowing producers to benefit from the competition between traders, whilst still having access to informal credit.

For padhys, the main benefits of lending are to secure cotton supplies, reducing search costs and potentially achieving some economies of scale; and to increase the volume and market share of fertiliser and pesticide sales (particularly for those with input agencies). Lending may also be profitable in its own right, but apparently high costs to borrowers in the form of explicit or implicit ${ }^{11}$ interest rates reflect the high transaction costs and risks of lending. They are also competitively determined as credit-worthy zamindars are able to transfer their business between competing padhys.

The primary recommendation of this investigation is that the current liberal policy towards the cotton sector should be continued. While not requiring direct action, this is an important finding to help protect existing reforms, given the entrenched and antagonistic attitudes of many politicians, bureaucrats, and influential landowner organisations who view current marketing arrangements as exploitative and non-competitive. The priority and minimalist role of the state should be to sustain the beneficial model of private sector activity that exists; first, by maintaining and enhancing communications and transport infrastructure; second, by seeking to maintain a favourable market for cotton that calls forth supply from producers and investment by traders, processors, and other sources of capital, without employing unsustainable subsidies or protective trade policies. In the longer term, efforts should

${ }^{11}$ Via a lower price received for cotton, or a higher price paid for inputs. 
focus on banking reform and the development of viable and effective rural financial institutions. These have a broader role to play than simply the financing of seasonal working capital in agriculture, but would offer growers an alternative to interlocked loans from padhys, thereby further enhancing competition.

A more specific recommendation is that the adoption of cotton lint grades would encourage ginners to improve the quality of lint output. Ginners should have an incentive to voluntarily adopt a standardised grading system because of the premium they would get for higher quality grades. The implementation of seed cotton standards and the desired incentive effect for growers may be harder-though not impossible - to bring about. Efforts to encourage the adoption of nationally and internationally recognised grading standards should therefore be continued [Pakistan Cotton Standards Institute (1992)]. Practical means to spread the adoption of grading of both cotton lint and seed cotton need to be explored and promoted.

It is apparent that major reforms are required in the wheat distribution system. The government minimum support price, for most growers, is also effectively a ceiling price due to inter-district trade bans, which inhibit movement of wheat from surplus to deficit areas. Subsidised imports have a high fiscal cost and also depress domestic prices. Recent price levels have provided little incentive to produce for the market, discouraging intensive production methods and leading to stagnation of yield levels. They have also encouraged the potentially risky practice in relation to pests and disease, of keeping cotton in the field for much of the rabi season, at the expense of some or all wheat cultivation. Although the yields of additional cotton pickings diminish, the marginal costs in this practice are limited to picking, and are low compared to the costs of sowing wheat.

The procurement and storage system encourages corruption and "disappearance" from godowns of publicly owned wheat stocks. The transport contracting system lacks competition, providing no incentive to reduce costs, and also encourages corruption in the award of contracts and in the form of payment for costs not incurred and transport not undertaken. The provision of subsidised wheat quotas to flour mills, again, has a high fiscal cost, and provides no incentive to improve milling efficiency. It also encourages further corruption and sale of wheat quota onto the free market either in Pakistan or neighbouring countries.

Given the endemic weaknesses of enforcement institutions in Pakistan, it is hard to see how the negative effects of public sector intervention in the wheat market can be reduced without radically altering or removing the interventions themselves. Improvements in monitoring and a strengthening of enforcement institutions may remove some of the inefficiencies and abuses in the long term but are unlikely to be effectively implemented in the short or medium term.

The obvious recommendations for policy reform are to liberalise farmgate prices, reduce the state's role in procurement, and privatise government godowns. Future research should concentrate on how this might best be achieved. Attention 
should be given to the conditions that are necessary for the private sector to take over and finance storage activities, and to ways of minimising price instability. ${ }^{12}$ The possibly harmful impact of higher flour prices on poor consumers also needs to be addressed, although it is likely that the increase in flour prices resulting from liberalisation would be considerably less than the increase in farmgate wheat prices. The effective role played by the private sector in cotton marketing suggests that the liberalisation of wheat marketing could be beneficial to growers, consumers, and the economy as a whole. The findings of this study also suggest that the process of transition may be relatively straightforward, given the existing high level of participation in wheat marketing by padhys, and the access to at least the minimum levels of infrastructure and working capital required. The institutional arrangements, namely, interlocked transactions in the informal credit market, are also in order and could finance investment in intensified wheat production by farmers in response to improved price incentives.

\section{REFERENCES}

Abid, S. K. (1980) Marketing Infra-structure, Margins and Seasonal Price Variation of Selected Agricultural Commodities in Sindh Province of Pakistan. Final Report Rice. Tando Jam, Department of Agricultural Economics and Rural Sociology, Sindh Agricultural University.

Alderman, H. (1988) The Twilight of Flour Rationing in Pakistan. Food Policy 13 (August), 245-256.

Alderman, H., M. G. Chaudhry, et al. (1988) Household Food Security in Pakistan: The Ration Shop System. International Food Policy Research Institute, Washington, D.C., and Pakistan Institute of Development Economics, Islamabad.

Cornelisse, P. A., and S. N. H. Naqvi (1989) An Appraisal of Wheat Market Policy in Pakistan. World Development 17:3 409-419.

Faruquee, R. (1995) Government's Role in Pakistan Agriculture. Washington, D.C., World Bank, South Asia Country Department I, Agriculture Operations Division.

John Mellor Associates Inc. (1993) Agricultural Prices Study. Islamabad, Planning and Development Division, Government of Pakistan.

Kamdar, M. S. (1986) Government Intervention in Agricultural Marketing A Case Study of Pakistan. Pak. J. AAEVS 2:1\&2 31-38.

Khan, M. H. (1994) The Structural Adjustment Process and Agricultural Change in

${ }^{12}$ Alderman (1988) noted that wheat policy goals after flour rationing were: constant seasonal prices, uniform pan-territorial prices, and an active private sector. Cornelisse and Naqvi (1989) suggest that the first two of these were being achieved at least in part because of government procurement measures. However, Alderman's prediction that the first two goals were incompatible with the third because incentives did not exist for storage and trade in wheat for private wholesalers has been shown to be valid. Incentives for private trade have only arisen more recently from the failure of the procurement system to stabilise open market wheat prices and to control "leakage" from government stores to the market, and from other corrupt practices. 
Pakistan in the 1980s and 1990s. The Pakistan Development Review 33:4 533591.

Khushk, A. M., I. Pirzada, et al. (1988) Cotton Production and Technology in Sindh. Tando Jam, Agricultural Economics Research Unit (PARC), Agricultural Research Institute, Tando Jam.

Memon, R. A. (1978) Marketing Infra-structure, Margins and Seasonal Price Variation of Selected Agricultural Commodities in Sindh Province of Pakistan. Volume 1, Banana, Dates and Mango. Tando Jam, Department of Agricultural Economics and Rural Sociology, Sindh Agricultural University.

Pakistan Cotton Standards Institute (1992) Standardisation of Raw Cotton in Pakistan. Karachi, FAO/UNDP/PAKL/86/003.

Qureshi, S. K. (1974) The Performance of Village Markets for Agricultural Produce: A Case Study of Pakistan. The Pakistan Development Review 13:3 280-307.

SDSC (1991) Baseline Report, Left Bank Outfall Drain Stage I, Socio-economic Impact Evaluation. Hyderabad, Sindh Development Studies Centre.

Siddiqui, S. A. (1979). Marketing of Agricultural Products in Sindh. Tando Jam, Department of Agricultural Economics and Rural Sociology, Sindh Agricultural University.

Smith, L. E. D., and M. Stockbridge (1997) Report on the Study of the Cotton and Wheat Marketing Systems and the Provision of Pre-Harvest Services in Sindh Province, Pakistan. Department of Agricultural Economics and Business Management, Wye College, University of London.

Stockbridge, M., L. E. D. Smith et al. (1998) Cotton and Wheat Marketing and the Provision of Pre-Harvest Services in Sindh Province, Pakistan. In A. Dorward, J. Kydd and C. Poulton (eds) Services for Smallholder Agriculture under Liberalisation: A New Institutional Economics Perspective. (Wallingford, UK: CAB International). 